\title{
The Values of Multicultural Education in Munanese Traditional Culture
}

\author{
La Ode Ali Basri ${ }^{1}$, La Aso ${ }^{2}$, Abdul Halim Momo ${ }^{3}$, I Wayan Mudana ${ }^{4}$, La Taena ${ }^{5}$, Salniwati ${ }^{6}$, La Janu ${ }^{7}$ \& Aswati ${ }^{1}$ \\ ${ }^{1}$ Dept. of History, Faculty of Cultural Studies, Halu Oleo University, Kendari, Indonesia \\ ${ }^{2}$ Dept. of Literary Studies, Faculty of Cultural Studies, Halu Oleo University, Kendari, Indonesia \\ ${ }^{3}$ Dept. of Civics Education, Faculty of Teacher Training and Education, Halu Oleo University, Kendari, Indonesia \\ ${ }^{4}$ Dept. of Sociology, Faculty of Law and Social Sciences, Ganesa Education University, Singaraja, Indonesia \\ ${ }^{5}$ Dept. of Social Sciences Education, Faculty of Teacher Training and Education, Halu Oleo University, Kendari, \\ Indonesia \\ ${ }^{6}$ Dept. of Archaeology, Faculty of Cultural Studies, Halu Oleo University, Kendari, Indonesia \\ ${ }^{7}$ Dept. of Anthropology, Faculty of Cultural Studies, Halu Oleo University, Kendari, Indonesia. \\ Correspondence: La Ode Ali Basri, Dept. of History, Faculty of Cultural Studies, Halu Oleo University, Kendari, \\ Southeast Sulawesi, Indonesia. Tel: 62-8-1341-797344. E-mail: basri.uho74@gmail.com
}

Received: November 19, 2016

Accepted: January 3, $2017 \quad$ Online Published: February 28, 2017

doi:10.5539/ach.v9n1p33

URL: http://dx.doi.org/10.5539/ach.v9n1p33

\begin{abstract}
This study aims to reveal elements of multicultural education in traditional culture of Muna, one of ethnic groups in Southeast Sulawesi, Indonesia, by employing a descriptive qualitative research method. Main informants of the study included maestros of tradition preservation, traditional prominent figures, main figures of the society, and youth figures. Data were collected by conducting participatory observations, in-depth interviews, and focused group discussions. The data were then analyzed by performing data reduction, data presentation, and conclusions drawing. Findings of the study showed that Munanese traditional culture contains values of multicultural education such as appreciation of others' services and creations, harmoniously living with others, awareness of a fundamental nature of human as a creature subject to weaknesses, advocating the need to exhibit noble characters, recognition and respect of others' right, high work ethic, and gender neutrality. These values of multicultural education are embedded in taboo tradition, traditional sayings, folklores, and traditional riddles.
\end{abstract}

Keywords: traditional culture, multicultural education

\section{Introduction}

Every society has its own traditional culture and local wisdom which make it unique and at the same time becomes the characteristic of the society. Amid the crisis of values of modern culture today, traditional cultures are now becoming an area of investigation for many circles, since it is believed that traditional cultures contain many local wisdoms that can offer solutions to the crisis of modern culture (Herman, 2016). One form of local wisdoms contained in traditional cultures is ancient teaching about values of multicultural education that are rooted from experiences in life and are resulted from interactions between local people with their natural surroundings (Mungmachon, 2012).

Multicultural education is a process of developing all human potentials to respect plurality and heterogeneity, which is a natural consequence of a diversity in cultures, ethnic groups, and denominations (Naim, et al, 2008). In a similar vein, Mahfud (2009) states that multicultural education can be seen as an education of cultural diversity, which views diversity as a natural necessity (or even a manifestation of God's grace) to whichwe should assume tolerant, egalitarianattitudes. Proposing a similar opinion, Banks (2007) defines multiculturaleducation as a social policy that is based on certain principles of cultural preservation and showing respect to every member of a society, and is practiced by all members of the society, to manifest a democratic life that is ideal for a nation.

In line with this, Bennet (2003) maintains that multicultural education concerns with how different ethnic groups determine which foreign culture they wish to adopt in accordance to their view on other groups so that they will be able to embrace other cultures without jeopardizing or sacrificing their own culture. 
Studies on the cultural-based values of multicultural education have been conducted by a number of researchers, for instance Convertino (2016), who points out that multicultural education enables people to have intercultural dialogues and share their experiences. Yeh et al. (2005) conducted a study on Korean immigrant youths and found thatthe youths used Korean norms and cultural values to cope with a change of identity and cultural acculturation, especially American culture. A similar study was carried out by Chen (2015) who investigated Aboriginesin Taiwan. It was found that experiences in socializing with other Aborigines and learnings of the traditional culture of indigenous people had created a more positive ethnic identity. Besides, international performances had allowed them to gain self-confidence and view from various perspectives. An analysis by Clark et al. (2002) suggested that multicultural education can bridge a socio-economic gap experienced by students in digital access. It can alsodevelop students' sensitiveness to their environment, and enable them to work with people coming from different socio-economic backgrounds.

In Indonesian contexts, investigations into multicultural education have been carried out by, among others, Yusri (2008) who focused on the multicultural education taught by religions in Indonesia. Result of the study showed that principles of multicultural education have long existed in the life of Indonesian people since pre-Indonesian age, which indicates that during Majapahit time people with different beliefs lived multicultural life in harmony. Garna (1999) studied Bedouin people and reported that this ethnic group has an instrument of social control called pikukuh, which is a set of rules that govern human life in its relation with other humans, God, and the environment. A study by Ganap (2012) on native multiculturalism and ethnicity showed that oral traditionfound in every indigenous ethnic group contains values of multiculturalism.

The values of multicultural education found in the cultures of people in Southeast Sulawesi have also been investigated by some researchers. For example, Tarimana (1989) studied Tolakinese ethnic group and revealed that Tolakinese people held on five customary circles that serve as the guiding principles of their life and their view of life. One of the circles calledsara mbeduluconcerns with a customary unity and union or kinship.A study of the traditional culture of Munanese people was conducted by Taena et al. (2016). The study showed that this ethnic group has a set of rules called falia which governs how to respect, maintain, and preserve forests.It must be noted, however, that the noble teachings of Munanese ethnic group about respecting and celebrating diversity within principles of equality are found not only in the philosophical view of taboo and prohibition (falia), but also in traditional sayings, folklores, riddles, and other rituals.

\section{Research Method}

Thisstudy was conducted in Muna, a regency in Southeast Sulawesi, Indonesia, and lasted for six months. Several techniques of data collection were used in the study, including: (1) participatory observation on ritual activities containing elements of multicultural education, (2) in-depth interview withmaestro and preservers of tradition, (3) focused group discussion involving prominent figures in the society, youth figures, traditional figures, and other members of the society.

Data were analyzed using a descriptive-qualitative method, which comprises of the following stages: (a) data reduction, in which all data obtained from interviews, observation, study of literature, and focused group discussion were organized, divided one by one, and grouped based on types. Then, the data were reduced in order to eliminate least relevant data. This was followed by making an abstaction and organizing data into several units; (b) data display, in which data were presented through a process of categorization and grouping according to units of analysis with the aim of improving the data. Next,some relationships between categories wereestablished, each category of datawas compared to other categories, and the meanings of each data relationship were interpreted; (c) drawing of conclusions, which was based on the results of data interpretationand supported by valid and consistent evidences.

To conduct the study as planned, several medium and research techniques were employed, including data cards, interview guidelines, and photo camera or video camera to record observation and interviews.

\section{Results and Discussion}

\subsection{Values of Multicultural Education in Munanese Culture of Falia (Prohibition)}

\subsubsection{Appreciating Others' Services and Creation}

One of Munanese local wisdoms which contains values of multicultural education is the tradition offalia (prohibition). Among the values of multicultural education embedded in this tradition is that everyone should learn to appreciate what other has done and created. As humans, we have to respect each other's work, creation, and ideas. Appreciating others' creations and services is one of ways to build a harmony and concord in human life as well asto manifest a social life in which people respect and appreciate each other in accordance to one's degree and 
dignity as a human being. This conception can be found in the following concept of prohibition that is practiced by Munanese people: "ofalia detongka kahitela atawa dotobhe ane minaho natumandakie parikano rampano mina nakoinawaane kahitela be pae (it is prohibited to harvest corns or rice if it is not began by a parika (farm shaman) yet. Parika is a man wo has rendered a service of sowing seeds and started planting (corns/rice) so he must be given a privilege to be the one who start a harvest. The tradition of allowing parika to go first in a harvesthas been deeply embedded in the farming culture of Munanese people.

Another value of respecting others' creation and services taught in pemali tradition is a prohibitionof leaving a house when the host has served food or drink. "Ofalia doere dokala anekaalahino nefumaa atawa okaforoghu nentaa-ntamoa, rampano notikini ane lalo (Leaving a house when food or drink has been served by the host of the house is prohibited because it can cause bad feelings). Serving food or drink is meant by a host to respect and honor us, so we should appreciate it by accepting the food or drink. Leaving the house without consuming, or at least tasting the food or drink a little, can make the host disappointed.

The next values of faliaare appreciation and respect for others' kindness. In a social life, appreciating and respecting others' creation can bring about a social harmony, allowing people to live a calm, peaceful life where everyone is aware of the importance of respecting and appreciating each other. Besides, respecting other's creation and services is considered a commendable attitude since it reflects the creators' personality as a human being that wishes to be respected.

The symbolic teaching of the need to appreciate everyone's task and role can also be found in falia dengkora ne kandulua, noko kawio ane koro (Sitting on a pillow is prohibited because it can cause boil on the butt). In addition to containing a moral message about living a simple life and treating everything proportionally, this prohibition also teaches about a moral, i.e. respecting the difference in tasks and roles played everyone. Sitting upon a pillow can torn it, and if this happens it needs mending, which means spending some money to buy a needle and threads. Also, pillows are supposedly used for cushioning head, not butt.

\subsubsection{Respecting others' belongings}

Also found in the pemalitradition of Munanese ethnic group is an ethic regarding ownership of properties. This can be seen inthe following statement:"falia depake/deala hakunaasi rampano nobinasaane mbhada dhunia ahera" (it is prohibited to use/take hak naas (others' rights) because doing so will result in physical perishin this world and in the hereafter).The terms haku naasi 'hak naas' in the falia"pemali" statement above is a symbolic meaning of 'others' rights' of either movables or immovable goods. Taking or using haku naasi, or 'hak naas', is strictly prohibited in Munanese societies. It is believed that those who violate the prohibition will perish in this world and in the hereafter, and that they will not be safe in in this world and in the hereafter. Therefore, falia"pemali" teaches us to respect what other people own, and prohibits us from justifying any means to gain what we wish, including amassing wealth.

\subsubsection{High Work Ethic}

“....ofalia dempolodo-lodo samintaeno, mina dakoradhakiane" (it is prohibited to nap in the morning because doing so can reduce our sustenance). Taking a nap in the morning is extremely disliked by Munanese people because it indicates laziness, ignorance, lack of creativity, and a tendency of passiveness. Those who have this habit will never go forwards, and their life will tend to remain static since they are constantly occupied with feelings of laziness, misery, apathy, and they can easily develop envy and jealousy towards others. This advice contains spirits of hardworking and responsibility. The concept of working hard reflects a motivation to succeed in life and to change into a better life. The change is possible only if we are strongly motivated to succeed, and therefore we have work hard and learn faster. We will have a special feeling of satisfaction if we can accomplish our task perfectly.

In a socio-cultural perspective, pemalior prohibition is seen as a norm of decency because it contains a set of universal values of humanity that can be used by the society to guide its people into a harmonious, orderly social life.In Pranowo's view (1998), in Taena et al. (2013), pemalior known anthropologically as taboo (Basri, 2010) is a tradition of prohibition that becomes one of a society' views of life and lifelines. Embedded in the tradition are elements of ethic and manner education aimed at creating great personalities in the society. Thus, pemaliis a means of self controlfor every individual, as well as a means of social control for the societythat prevents them from doing ill-natured actions, restrain themselves from any acts that violate any laws, including customary laws and religious laws, norms of ethic and decency, and cause no destructions to the nature (Laepe, 2006). 


\subsection{Values of Multicultural Education in Folklores}

3.2.1 The Legend of Kabhawono Kamonsope bhe Kabhawono Sabha Mpolulu (Kamosope and Sabha Mpolulu Mountains)

......Pada amaitu nofekirimi We lalono, inodi ini o moghane, anoa o robhine tungguno kabhawono Kamonsope. Ambanoa amosurue amalae labhihaku. Nopogaumu tora tungguno kabhawono Kamonsope kaasi, ambanoa aembali robhine ini akiido omosuru kanau. Nofetingke wambano nagha kansuru noamara tungguno kabhawono Sabha Mpoluku. Noalamo sinapano maka notemba tungguno kabhawono Kamonsope. Bhabhaano notembae miina nakumantibhae. Nefohala tungguno kabhawono Kamonsope. Nofeendua notembae miina narumato bhatuno. Pada amaitu nobholosimo dua tungguno kabhawono Kamonsope. Sepaku notembae,, nokantibhae nopoweta peda kasabhano polulu. Katikonahanomo kabhawo Sabha Mpolulu...

Translation: ......Sabha Mpolulu said, "I am a man, you (Kamosope) are a woman, I will force you to allow me to take your water. The watcher of Kampsopemountain answered, "please have a pity on me, I know I am a woman, but please do not force me... But Sabha Mpoluluremained forceful so a battle broke between them and ended up with the defeat of Sabha mpolulu....

The excerpt above shows that Sabha Mpoluluwanted to establish his dominance over Kamosope. However, Kamosope knew that she was being subordinated by Sabha Mpolulu, prompting Kamosope to fight against the gender unfairness. Following Pranowo (2013), what Sabha Mpolulu did was an effort to maintain a patriarchycal dominance, with the intention of forcing women to be subjugated under a patriarchycal culture. What was done by Kamosope, on the other hand, was a fight of women to set themselves free from men's shadows, and to remove an image of minority and weakness commonly associated with women. It can be inferred from the story above that the concept of emancipation and gender equality have been around in Munanese societies since a very long time ago. The story also delivers a message of multicultural educationregarding the need to respect and recognize human rights, in particular byupholding the honor of women and maintaininggender neutrality (Basri, 2016).

\subsubsection{A Folklore of "dahu mogharo" (A hungry dog)}

..." Nando dahu nogharo, maka mina nakoghoti, dadihanomo nokola nekapihi nefumaano. Neghawa kaawu kafumaano netou toumo nobhasi bhaihino, norato kaawu bhaihino dofumaemo do bhari bharihaane. Gara dahu merakono kafuma maitu minaho naowehi, nokalamo tora nomoisa nekapihi kafumaano, neghawa kaawu kafumaano minamo namoratoda bhaihinoa nofumaemo nomisahaane. Welo wuntano nofuma gara bukuno kafumaano maitu notikai wewunghuno mina namoolinoalietanomatehighoomo...".

This story tells about the life of a hunting dog. After successfully catching a prey, the dog called other dogs to come and enjoy the food together. The hunting dog, however, was not satisfied with the food. Still feeling hungry, the dog hunted other preys. This time the dog decided to eat the food himself, no more sharing it with other dogs. But instead of feeling fully satisfied, the dog died because a bone stuck in his throat. What we learn from the story is a moral that, while gaining success after successis important, we should do it without hurting and forgetting other people. In fact, other people should be able to share our success. We must not be too greedy.

\subsection{Values of Multicultural Education in Traditional Sayings}

\subsubsection{Noble Characters}

1) Mahingga omangka te towuno harimau, ani sonidhalangimu sala metaa, maka sadhia osalamati

"Although you are riding a tiger, you will survive as long as you are on the right way"

2) Doposabhangka bhe mie mbolakuno dombolaku dua, doposabhangka bhe mie potarono dopotaro dua

"Making friend with a thief will make you a thief, making friend with a gambler will make you a gambler as well"

3) Soano mie moghanea ane mie tumalono kaewano, tabea mie moghane mie tumalono nafusuuno

"one is not said an intrepid person only by defeating his adversary, he must also defeat his lust."

4) poangka-angka tao-popia-piara, poma masigho (no fighting with each other, nurturing, loving, and caring each other), poadha-adhati (respect others according to their customs), bhini-bhini kuli (try hurting yourself and feel the pain). 
5) Hansu-hansuru bhada kono hansuru liwu, hansu-hansuru liwu kono hansuru adhati, hansu-hansuru adhati kono hansuru agama (our body/soul may perish, but our land must never disappear, our land may perishbut our tradition must live, and our tradition may perish but our religion must keep standing).

\subsection{Values of Multicultural Education in Traditional Riddles}

\subsubsection{Awareness of Our Existence as Imperfect Creature}

Munanese traditional riddles are also rich of multiculturalism educational values, especially ones concerning human existence as imperfect creature so that we always need other people. This can be found in the following riddle..." "watawataangke, wutomu owurae, opobisaraamua miina..." (Riddle: you see yourself, but you cannot talk to each other.) The answer to this riddle is your shadow.

The words 'wutomuowura'symbolizes 'a man who sees his own image in a mirror', whereas "opobisaraamua miina"is a symbol of a man and his own image in the mirror that he cannot communicate with." Thus, the riddle implies that humans must be aware of their real existence as God's creature with limitations.

Similar to the riddle above, another one is concerned with a human's limitation. "katondono mie bhaimu owurae, katondo wutomu miina omorae..." (you can see other's fence,but you cannot see yours). The answer is our teeth. The word 'katondono' in this riddle refers to a symbolic meaning of our teeth, that are lined up like a fence, which cannot be seen without using an aiding tool. The riddle implies an allusion to human beings that are created by God with many limitations. Human eyes have limited sight so that they cannot see the teeth.

A traditional riddle which also concerns about the need to respect others is "watawataangke, o ghondo mie bhaimu owurae, oghondo wutomu miina omorae" (riddle: with it you can see others, but you cannot see it by yourself). The answer is "the eyes". The words 'ghondo' and 'wura' symbolize the function of 'bunsolo' (eyes). This riddle is another allusion to human beings, to remind them that God created them with limited potentials, in this case their visual sense, i.e. the eyes.

\subsubsection{Respect Each Other and Live Side by Side in a Harmony}

Contained in Munanesewatawatangke (traditional riddle) is a symbolic message about the importance of living side by side with others in a harmony. This moral message is found in the following riddle "watawataangke: katokano dopokakopu, dapowura miina" (riddle: they embrace each other but they are unable to see each other). The answer is house poles. The word 'dapowuramiina' refers to a contradictory ideal of embracing people, which in this case is analogous to house poles that stick to each other. Watawatangke is a symbol of the social relationship among Munanese ethnic groups which is continually maintained because it is believed that nobody knows what others exactly feel nor does anyone have a completely identical personality with others.

Another watawatangke (riddle) which gives a symbolic message about the need to live with and respect others is "watawataangke: desumbele karambau miina damata, desumbele tomi dopata". (Riddle: slaughtering a buffalo is insufficient, slaughtering a sparrow is sufficient). The answer to the riddle is a wall lamp. Themoral message of the riddle is that the quality of anything, be it animate or inanimate objects, is not determined by the size. What matters is how useful the thing is. A small kantale ngkoradenoted by 'desumbele tomi' is believed by Munanese ethnic group to be capable of shedding a very bright light in a pitch-darksituation (Salniwati, 2014).

Looking into the fragments of Munanese culture and tradition described above, it is apparent that humanism values do exist and are in line with concept of multicultural education, and they can guide us in our efforts of making our life more civilized and humanistic within a frame of cultural, ethnic, and religious diversity.Culture is only a symbol or sign that can guide people in their interaction within their social life, as well as in their interaction with the nature and God. This view is sharedby Cassirer (1990) who points out that humans often use symbols in their actions for the symbols enable humans not only to find ways of coping with various problems of their life, but also to deal with their nescience about many things.For this reason, Eco (2004) calls humans as homo interpreticum owing to their ability to interpret signs or symbols.According to Eco (2004), our worldis full of signs, and we should try and interpret the signs so that they can be used to guideour life.In relation to this, revealing and identifying the values of multicultural education embedded in Munanese traditional culture can be seen as a crystallization of our effort to try and make sense of the cultural symbols of this ethnic group, and we can use it to bind people together.

\section{Conclusion}

It can be concluded from the discussion above that multiculturalism educational values are embedded in Munanese traditional culture, especially in the tradition of pemali (taboo), traditional sayings, folklores, and traditional riddles. Among these values are the need to appreciate others' service and creation, to live side by side in a 
harmony, and to be aware of our true nature as God's creature with many weaknesses. In addition, the traditional culture teaches the importance of exhibiting noble characters, recognizing and respecting the rights of other people, and upholding a high degree of work ethic and the values of gender equality.All these indicate that Munanese people hold on a unique moral philosophy, one that is in accord with social mentality and characteristics that they recognize and agree with. The moral philosophyof multiculturalismcan be employed to bind people together and guide them towards a sustainably harmonious life for the entire humanity.

\section{Reference}

Anonymous. (2016). StarategiPelestarianBudayaLokal Muna. LaporanPenelitian. Kendari: UniversitasHalu Oleo, Indonesia.

Banks, J. A. (2007). Educating citizens in a multicultural society. New York: Teachers College Columbia University.

Basri, A. O. L. (2010). Pemanfaatan Kearifan Lokal Sebagai Modal Sosial Budaya Dalam Pemberdayaan Masyarakat Pesisir Etnik Bajo. Disertasi. Udayana: Denpasar, Indonesia.

Bennett, C. I. (2003). Comprehensive multicultural education: Theory and practice. Boston: Pearson Education, Inc.

Cassirer, E. (1990). Manusiadan Kebudayaan: Sebuah Eseitentang Manusia. alihbahasa: Alois A. Nugroho. Jakarta: Gramedia, Indonesia.

Chen, M. S. (2015). Dancing with Ethnic Identities: An Aboriginal Dance Club in a Taiwanese Middle School. International Journal of Multicultural Education, 17(2), 20-34.

Clark, C., \& Gorski, P. (2002). Multicultural education and the digital divide: Focus on socioeconomicclass background. Multicultural Perspectives, 4(3), 25-36.

Convertino, C. (2016). Beyond Ethnic Tidbits: Toward a Critical and Dialogical Model in Multicultural Social Justice Teacher Preparation. International Journal of Multicultural Education, 18(2), 125-141.

Eco, U. (2004). Tamasya Dalam Hiperealitas. Yogyakarta: Jalasutra, Indonesia

Fakih, M. (2000). Masyarakat Sipil untuk Transformasi Sosial: Pengelolaan Ideologi di Dunia LSM Indonesi. Yogyakarta: Pustaka Pelajar, Indonesia

Ganap, V. (2012). Konsep Multikulturaldan Etnisitas Pribumidalam Penelitian Seni. Humaniora, 24(2), 156-167

Garna, K. J. (1999). Metode Penelitian: Pendekatan Kualitatif. Bandung: Primaco Akademika, Indonesia.

Herman, K. D. R. (2016). Traditional knowledge in a time of crisis: climate change, cultureand communication. Sustainability Science, 11(1), 163-176.

Laepe, A. (2006). Analisis Semiotik Atas Lirik Kantola: Sastra Lisan Daerah Muna. Kendari: Kantor Bahasa Provinsi Sulawesi Tenggara, Indonesia.

Mahfud, C. (2009). Pendidikan Multikultural. Yogyakarta: PustakaPelajar, Indonesia.

Mbete, M. A. (2006). Kazanah Budaya Lio-Ende. Yogyakarta: Pustaka Larasan, Indonesia.

Mungmachon, R. M. (2012). Knowledge and Local Wisdom: Community Treasure. International Journal of Humanities and Social Science, 2(13), 174-181.

Naim, N., \& Sauqi, A. (2008). Pendidikan multikultural: konsep dan aplikasi. Ar-Ruzz Media.

Pranowo, B. (1998). Islam Faktual Antara tradisi dan Relasi Kuasa. Yogyakarta: Adicita Karya Nusa, Indonesia.

Pranowo, Y. (2013). Identitas Perempuan Dalam Budaya Patriarkis: Sebuah Kajian Tentang Feminisme Eksistensialis Nawal El Sa'adawi Dalam Novel Perempuan Di Tititk Nol. Melintas An International Journal of Philosophy and Religion, 29(1), 56-78.

Salniwati. (2014). Watawatangke: TradisiLisanEtnis Muna. Tesis. Kendari: UniversitasHalu Oleo, Indonesia.

Taena, L, Basri, A., Ode, L., \& Laepe, A. (2013). Dimensi Pedagogik Dalam Makana Budaya Tradisi Falia Pada Masyarakat Muna. Jurnal Mudra SeniBudaya, 29(1), 91-100.

Taena, L., Sailan, Z., Nalefo, L., Basri, A., Laepe, A., Samsul, S., ... \& Kuasa, W. (2016). The Cultural Tradition of "Falia" in Preserving Forest by Munanese Ethnic. Journal of Sustainable Development, 9(5), 200-206.

Tarimana, R. A. (1989). Kebudayaan Tolaki. Jakarta: Balai Pustaka, Indomesia 
Yeh, C. J., Pei-Wen, M., Madan-Bahel, A., \& Hunter, C. D. (2005). The cultural negotiations of Korean immigrant youth. Journal of Counseling and Development: JCD, 83(2), 172-182.

Yusri, M. (2008). Prinsip Pendidikan Multikulturalisme dalam Ajaran Agama-agama di Indonesia. Jurnal Kependidikan Islam, 3(2), 1-22.

\section{Copyrights}

Copyright for this article is retained by the author(s), with first publication rights granted to the journal.

This is an open-access article distributed under the terms and conditions of the Creative Commons Attribution license (http://creativecommons.org/licenses/by/4.0/). 